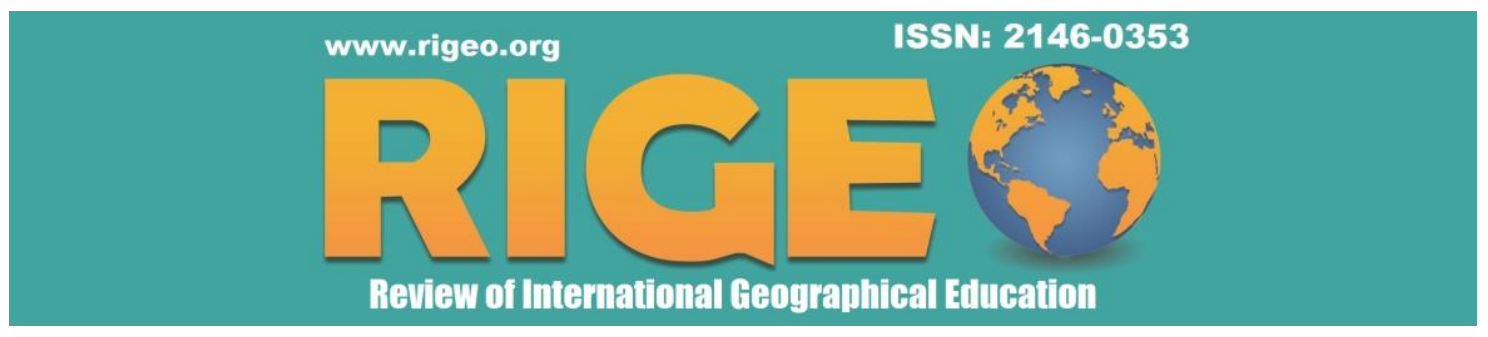

(C) RIGEO, Volume 10, Issue 1 (Special Issue), 2020

To cite this article: Gül, S. (2020). A Case Study on the Urban Perception of Disabled Students in Samsun (Turkey). Review of International Geographical Education (RIGEO), 10, (1), Special Issue, 226-248. Retrieved from http://www.rigeo.org/vol10no1/Number1Spring/RIGEO-V10-N1-11.pdf

DOI: 10.33403 rigeo.677322

Submitted: November 01, 2019

Revised: February 18, 2020

Accepted: February 25, 2020

\title{
A Case Study on the Urban Perception of Disabled Students in Samsun (Turkey)*
}

\author{
Seyfullah GÜL ${ }^{1}$ \\ Ondokuz Mayıs University, Samsun, TÜRKİYE
}

\begin{abstract}
Individual differences, especially physical disabilities, play a significant role in people's perception of their living places and their attitudes in these environments. Accordingly, the starting point of the present research is based on the possible contributions and developments of the implementations and studies partly eliminating the negative aspects of individual disabilities to the perceptions and information of the disabled people regarding the physical and social environment that they live in. The research aims to determine the impacts of time and experience on the recognition of the historical, cultural, and natural heritage properties of Samsun by the disabled students, on the analysis-based acquisition process of this information, and on the development and alteration of the disabled students' knowledge and perceptions regarding these properties. Within the scope of this purpose, the study has been carried out with a one-group pretest-posttest design recognized as the weak experimental design in the category of the experimental method. The mind mapping technique has been used as the data collection tool of the study. In the research, it has been observed that the theme contents of the posttest mind maps of the disabled students regarding the values symbolizing Samsun city are richer than the theme contents of their pretest mind maps. In other words, it has been detected that time and experience create a positive effect on the knowledge and perception of the disabled students regarding Samsun. It is thought that projects for people with disabilities, sightseeing and observation activities or increasing the means to enable them to reach natural, historical and cultural values will positively contribute to the knowledge and perceptions of disabled people about the values of the cities they live in.
\end{abstract}

Keywords

Disabled students; Samsun; Provincial perception; Sightseeing; Mind mapping

\footnotetext{
*A portion of this research was presented in 2. International Congress on Geographical Education (UCEK/ICGE-2019), 3-5 October 2019, Eskişehir-Turkey.

${ }^{1}$ Assist. Prof.; Ondokuz Mayıs University, Faculty of Tourism, Department of tourism guidance, Samsun, Turkey, seyfullah.gul [at] omu.edu.tr, ORCID: 0000-0002-5166-454X
} 
Individual differences are one of the most evident truths in our environment. Undoubtedly, individual differences are the basic characteristics that distinguish a person from another. These differences might be physical or they may derive from cognitive or emotional features, people's interests, skills, etc.. Especially, physical disability assumes an important position among all individual differences. Because the effect of the state of bodily disability on individuals ' perception of the place they live in and the formation of spatial cognitive maps that guide their behavior in that place is emphasized by the researchers (Downs \& Stea, 1973). Ar1 (2017, p. 13). In other words, we cannot deny the impacts of age, gender, interests, desires, and physical disabilities on the knowledge, idea, and perception of the individuals regarding a location apart from the physical and social conditions of the environment.

When the diversity of disability types and the intersection of disability conditions with other disciplines are taken into consideration, it has been emphasized that behavioral geography research related to the attitudes of the disabled people is a critical social issue that has been ignored for a long time (Gleeson, 1996, p. 387). On the other hand, it has been also seen that the geographers have been interested in the problems of the disabled since the 1930s (Zajadacz, 2015). Especially toward the end of the $20^{\text {th }}$ century, the analysis of the research and understanding methods for the comprehension of disabled people's world and experiences through behavioral geography has increased the calls for geographic studies both for the disabled people and their geography (Golledge, 1993; Jacobson, 2016). Disability is a type of pressure on the socio-spatial attitudes of an individual. In other words, numerous barriers limit the behaviors of the disabled in the natural environment. When the barriers created in the social environment by the executives and urban planners ignoring the disabled are also taken into consideration, it is seen that the world has become a place where the disabled cannot live. For this reason, there is a greater need for geographic studies that will be carried out for the disabled by the geographers who play a significant role in the field of geography, a science of location, and in the management of this location. First, these studies will become a guide for the determination and amelioration of the physical borders for the disabled in the natural environment because natural conditions create numerous obstacles that the disabled cannot overcome by themselves and geographic information can find the solutions to eliminate these obstacles. Secondly, the aforesaid studies demonstrate the leading role of geography in terms of mapping the natural and human-based barriers and environmental changes in the places where the disabled people live (Gleeson, 1996, p. 393). For this reason, the present study is quite significant for illustrating the changes in the perceptions of the disabled about the places and cities where they live with the help of limited activities or regulations.

When the literature is examined, it is seen that the geographic studies on the disabled have focused on three categories. The first one of these categories is based on the quantitative methods that mostly include statistical analyses. Among these studies, there are the samples of geographic analyses of general questionnaires on the disabled including the traditional medical geography -the disorders arising the disability- or the examples of the epidemiological studies, and the presentation of statistical summary data in the maps. The second category concentrates on the politically-informed studies 
elaborating on the disability issues from the perspective of social theory (cultural geography) and focusing on how the artificial environment can serve human beings. The category also includes other studies analyzing how the physical barriers can be influenced by the public policies and how the disabled people are exposed to the negative attitudes incompatible with the human rights (Park, Radford \& Vickers, 1998). The last category consists of the studies making the problems of the disabled people a current issue and searching for solutions to these problems by means of certain educational methods such as nature training and field surveys just like in the present study. Within these studies, Chouinard's (2001) work discusses why a sub-discipline such as geography of disability is needed from a critical perspective, and offers a detailed perspective on geography and disability about current research topics and future challenges. Gleeson (1999), on the other hand, has evaluated the relationship between location and disability and the impacts of geography on the formation of the experiences of disabled people in his study entitled the geography of the disabled. He has discussed the problems in a historical context by evaluating the disability, field and regulation theory, and he presented modern disability scenarios including the issues of accessibility regulations. On the other hand, Reginald G. Golledge is known to be a leading scholar with his studies on the locational attitudes of the disabled. Golledge $(1993 ; 1997)$ examined the impact of political correctness on the behavior of disabled people, policy and power in a study that traditionally have shown little interest in the population geography of disabled or disadvantaged relatively by criticizing the problems of this special population has emphasized the importance of geography to help cope with. In addition to all these realities, individuals ' perceptions of the place they live in and spatial cognitive maps that guide their behavior in that space can also change in a positive or negative way over time, depending on the experiences and experiences. (Temurçin \& Keçeli, 2015, p. 132). Sightseeing and field works are a teaching practice that changes the knowledge and perception of place, which geography educators focus heavily on, which highlights constructivism, self-regulation and independent thinking, and whose main purpose is to encourage active learning (Y1lmaz \& Bilgi, 2011, p. 692). In other words, the sightseeing method which is a traditional implementation being commonly used today can be defined as the analysis and discovery of the field through the direct, "on-site" contact between the geographer and the subject (Rediscovering Geography Committee, 1997). Blades (1990), emphasizes the significance of the sightseeing method in increasing the environmental knowledge of the individuals. Moreover, the sightseeing method can help the individuals concretize the abstract notions in human minds, comprehend new information, and put the complex data in practice more systematically (Akgün, Duruk \& Tokur, 2017; Aytaç, 2014; Açar, 2010).

Mind maps are an effective tool for the depiction of the way individuals perceive the place in which they live and for the embodiment of spatial knowledge. In general, when the literature is examined, it is noted that mind maps are often used in behavioral geography studies. Under a main heading of mind maps, topic that individuals all about the sub-titles, concepts, and words can be displayed graphically (Siochos\& Papatheodorou, 2011) a city, region or topic about the image, attitudes, perceptions or thoughts is one of the techniques used in presenting (Karataş, 2010, p. 162). Blades 
(1990) emphasizes that asking individuals to draw mind maps is a frequently used method for exporting individuals ' environmental knowledge. In addition, mind maps enable people to describe the locational schemes created perceptively in their minds in line with their experiences, interests, and desires (Temurçin \& Keçeli, 2015, p. 125; Marvin Levine, 1980, p. 1). Moreover, these maps facilitate comprehension, clarify the thoughts, associate the ideas with new information, and correct the previous mislearnt concepts since they schematize the information in the form of a picture, symbol, figure, and graphic (Balım, Aydın \& Evrekli, 2006). This technique is seen to be used frequently in the empirical and theoretical studies in the social, economic, political, educational, medical fields, etc.. Among these studies, Blades (1990) has analyzed the test-retest reliability of the mind maps. Besides, it is observed that the mind maps are used in different fields in order to determine the key locations in a city (BrennanHorley, 2010), to examine the collective memory of a city (Haas, Levasseur, Béal, Charrier, Demoures, Kalampalikis \& Rampon, 2011), to analyze the impacts of geographical information on the foreign policy (Da Vinha, 2012), and to develop future scenarios (Goodier \& Soetanto, 2013). Gieseking (2013), on the other hand, has emphasized that the mind mapping method demonstrates the location-finding and experiencing techniques used by people, their visual-locational intelligence types, and the dynamics of human-environmental relations. In addition to all these studies, Reuchamps, Kavadias \& Deschouwer (2014) have underlined the problems in the land use by means of mind maps while Dernat, Johany \& Lardon (2016) have benefitted from the mind maps for analyzing the locational structure along the coasts. Wartmann \& Purves (2017) have shown that mind maps are efficient tools for reaching the objectives such as collecting locational data, visualizing the socio-locational processes, eliminating certain locational obstacles in the research, and developing the Geographical Information Systems. Wise \& Heckley-Kon (1990, p. 125), on the other hand, have pointed out that the mind maps drawn by the students are generally ignored as evaluative tools despite their potential benefits in the evaluation of the geographical information. Especially, Tunçel's study (2002) carried out on the perceptions of university students about the Islamic countries are quite significant in terms of being an empirical study in the field of geography in Turkey. The use of mind maps in geography have been exemplified with Aliağaoğlu's study (2007) performed on the city image with the use of mind map technique and Şeyihoğlu, Akbaş and Kartal's study (2012) based on the implementation of the notions and mind maps in the education of geography. In the later years, it is observed that numerous studies have been carried out on the subjects of the academic success of the students (Karadeniz, Tangülü \& Melike, 2013), urban place perceptions of the international students (Temurçin \& Keçeli, 2015), geographic information sources (Akbaş \& Toros, 2016), use of these sources in the religious education (Türkyılmaz, 2017), evaluation of rural scape identity (Cengiz Gökçe \& Açıksöz, 2017), perceptions of the students about the refreshments facilities (Varnacı Uzun \& Altaş, 2018), and the positive sanitary impacts of extracurricular sightseeing activities on the disabled students (Pouya \& Demirel, 2018).

In recent years, there is an important increase in the number of disabled students receiving education at universities in Turkey. According to the data obtained by the 
Council of Higher Education (2020), the number of disabled students who start to receive education at universities has been recorded as 58679 in 2019 while this number was calculated as 47751 in 2013. Moreover, a significant increase has also been determined in the educational travels of the disabled to the locations other than the cities that they live in. These cities and their historical, natural, and cultural structure play a critical role in the positive image and perception of the relevant cities together with their characteristic natures. When the rareness of the studies on the perception and knowledge of disabled people about the cities where they live are taken into consideration, it is seen that the locational perception of the disabled is worth being studied in this sense. Besides, the thoughts of the inhabitants about their living places are one of the most interesting research areas for social scientists, city administrators, and educators.

From all these perspectives mentioned above, the present study is considered to make contributions to the promotions of the sightseeing and field surveys organized for the disabled in order to overcome the deficiencies in the research area. By being based on the preexisting theories and previous studies published in the relevant literature, the present study aims to answer the following research questions:

- Which themes can include the perceptions and knowledge of the disabled about Samsun city reflected in the mind maps of these disabled people?

- What are the values regarding Samsun city in pretest and posttest mind maps of the disabled students?

- Is there a significant difference between the pretest and posttest mind maps of the disabled students in terms of the values that represent Samsun city?

- What are the distributions of the values that represent Samsun city in the pretest and posttest mind maps of the disabled students?

\section{Methodology}

The study has been carried out with a one-group pretest-posttest design recognized as the weak experimental design in the category of the experimental method. Experimental design in social sciences is an efficient research method to test the causal relationships among the variables. Since the experimental studies enable the researchers to compare the changes in the dependent variable by interfering in the independent variable, it is easier to make causal interpretations among the cases in these types of studies (Gürbüz \& Şahin, 2014, p. 337). In the one-group pretest-posttest design, there is a random design group, and the pretest is applied to this group before an experimental intervention while the posttest is carried out after the implementation of the experiment (Özmen, 2019, p. 205). The use of the same evaluation tool in the pretest and posttest contributes to the enhancement of the internal validity of the research [Table 1]. 
Table 1

One-group pretest-posttest research design.

\begin{tabular}{cclc}
\hline Group & Pretest & \multicolumn{1}{c}{ Process } & Posttest \\
\hline $\mathbf{G}$ & $\mathbf{O}_{\mathbf{1}}$ & \multicolumn{1}{c}{$\mathbf{X}$} & $\mathbf{O}_{\mathbf{2}}$ \\
\hline $\begin{array}{c}\text { Disabled } \\
\text { Students } \\
(15)\end{array}$ & $\begin{array}{c}\text { Mind map } \\
\text { (Dependent }\end{array}$ & $\begin{array}{l}\text { Workshop about the characteristics } \\
\text { of natural and cultural heritage } \\
\text { values of Samsun and trips were } \\
\text { organized at five different districts } \\
\text { (Intervention). }\end{array}$ & $\begin{array}{c}\text { Mind map } \\
\text { (Dependent } \\
\text { Variable) }\end{array}$ \\
\hline
\end{tabular}

If the data obtained in this type of design reveal the presence of a statistically significant difference between the pretest and posttest points, this difference is accepted to derive from the intervention (Baştürk, 2009). However, there are certain critical problems regarding the validity of the design such as the lack of data in the background information of the students and doubts about the presence of a different event resulting in the differences between the pretest and posttest since there is no control (comparison) group (Özmen, 2019; Sözbilir, 2012). As it is not possible to find another group to compare with the experimental group in the current conditions, the present study has been carried out on a single group. The main reasons for this limitation can be listed as the participation of 15 persons in the study in total and the high error probability in case of the categorization of these students.

\section{Working Group}

The study has been performed on 15 physically disabled students between the ages of 18 and 28 receiving education in the associate degree and bachelor's degree programs at Ondokuz Mayıs University in the 2018 - 2019 academic year. The experimental group of the study has been determined with convenience sampling which is included in nonrandom sampling methods. Convenience sampling is the selection of the samples from easily accessible and applicable units in line with the limitations of time, money, and workforce (Canbazoğlu Bilici, 2019, p. 71). It is difficult to gather sufficiently comprehensive information that enables us to see the logical connections in and between the cases. Moreover, this sampling method is advised to be rarely used since it has a lower power of representation for the population of the research (Gürbüz \& Şahin, 2014 , p. 128). One of the basic problems in one group pretest-posttest model is the nonparticipation of the individuals taking part in the pretest due to different reasons. This study has also encountered with the aforesaid problem, and 5 participants have been excluded from the sampling group since they did not participate in the posttest, which has reduced the total number of the students from 20 to 15. Consequently, the study has been carried out on 15 students.

Eight of the participants in the study were male while seven participants were female. Two students receive education in the associate degree programs whereas thirteen students are trained in the bachelor's degree programs. The students receive education in the Faculty of Science and Letters (3 persons), in the Faculty of Sports Sciences (6 persons), in the Faculty of Education (3 persons), in the Faculty of Engineering ( 2 persons), and in the Faculty of Health Sciences ( 1 person). The 
participants in the study group have physical disabilities (six persons), visual disabilities (three persons), hearing disabilities (five persons), and albinic conditions (one person). Different educational contents have not been prepared in accordance with the disability types of participants in the study group; instead, the same educational content has been given to the whole group.

\section{Data Collection Tools and Collection of Data}

Mind maps have been used as the data collection tool of the study. Mind maps play a significant and historical role in the evaluation of the locational perception in geography (Gueben-Venière, 2011; Tümertekin \& Özgüç, 2009, p. 51). Mind maps or cognitive maps were defined by Downs \& Stea (1977, cited in Tümertekin \& Özgüç, 2007, p. 51) as a structure comprising the learning-training processes that enable the people to gather information about their spatial environment, to store this information, and to evoke and change it.

Before the implementation. This study has been performed with the use of the data obtained in "the Barrier-free Evliya Çelebis Project of OMU" implemented between March 2019 and June 2019 and supported with the code 16593 by the General Directorate of Project and Coordination in the Ministry of Youth and Sports within the scope of 2018-1 Special Calls of the Youth Projects Support Program.

This project has aimed to help the disabled students receiving education at OMU know each other, to promote the natural, historical and cultural values of Samsun city through the sightseeing method, and to change the perception about Samsun in a positive way. The participants of the project were selected from among the students who completed the application forms prepared in an interactive environment and who had not previously been in Samsun or had not resided. In order for these students to learn the natural history and cultural values of Samsun and experience them with sightseeing and observation studies, it is planned that the field work involving five districts on different dates for natural, historical and cultural values in different districts will be given by experts for 3 weeks and 9 hours in total.

After the orientation programs, the participants were asked to draw mind maps at the beginning of the project (March 2019) in order to determine their knowledge about the place where they live and their spatial attitudes. Before the creation of mind maps, the sampling group was informed by an expert about the drawing techniques of mind maps. At this stage, advisor officers who are educated in the field of description were appointed to help the visually impaired students create their mind maps while sign language experts were assigned to aid hearing-impaired students. No advisor was appointed for the students in other disability groups. Criticism of the mind mapping method suggests that people who are not trained in map drawing are unable to map the places they know on the inner city scale and require the ability to draw, not knowledge. (Tümertekin \& Özgüç, 2007, p. 2). For this reason, by taking the above-mentioned criticisms and the disabilities of the study group into account, the participants were given A4 papers at the center of which a blank map of Samsun without a scale and in the size of $5 \times 10 \mathrm{~cm}$ was present. At the second stage, the participants who sat down in separate seats in the same classroom were asked to write down the names of the places 
that they know in Samsun, to mark the locations of these places on the map, and to draw them. As the sampling group consists of disabled students, 1-1.5 hours have been given for the students to finish the task. These mind maps have been stored without being analyzed and examined.

Implementation process. At the second stage, the students in the study group took 9-hour theoretical courses in 3 weeks in which the natural, historical and cultural values of Samsun have been introduced by the academicians in the departments of history, literature, and geography within the scope of "The Barrier-free Evliya Çelebis Project of OMU". After the completion of these courses, research trips were organized in six different provinces of Samsun (Çarşamba, Bafra, Havza, Salıpazarı, Tekkeköy, and Vezirköprü) at different dates [Table 2].

Table 2

Theoretical Training, Field Trips and Activities

\begin{tabular}{|c|c|c|c|}
\hline $\begin{array}{l}\text { Theoretical } \\
\text { Training Subject }\end{array}$ & Learning Content & Field Trips & Activities \\
\hline $\begin{array}{l}\text { Cultural heritage } \\
\text { values of } \\
\text { Çarşamba district }\end{array}$ & $\begin{array}{l}\text { Training about the } \\
\text { characteristics of } \\
\text { cultural heritage values } \\
\text { of Çarşamba district. }\end{array}$ & $\begin{array}{l}\text { Çarşamba } \\
\text { District }\end{array}$ & $\begin{array}{l}\text { Visiting the Göğceli Wooden } \\
\text { Mosque and historical sites of } \\
\text { Çarşamba Distirct. }\end{array}$ \\
\hline $\begin{array}{l}\text { Natural and } \\
\text { cultural heritage } \\
\text { values of Ayvacik } \\
\text { district }\end{array}$ & $\begin{array}{l}\text { Workshop about the } \\
\text { characteristics of } \\
\text { natural and cultural } \\
\text { heritage values of } \\
\text { Ayvacik district. }\end{array}$ & $\begin{array}{l}\text { Ayvacik } \\
\text { District }\end{array}$ & $\begin{array}{l}\text { Visiting of Yeşilırmak Valley } \\
\text { and Hasan Ugurlu Dam Lake } \\
\text { and Suat Uğurlu Dam Lake. }\end{array}$ \\
\hline $\begin{array}{l}\text { Cultural and } \\
\text { historical heritage } \\
\text { values of } \\
\text { Tekkeköy district }\end{array}$ & $\begin{array}{l}\text { Workshop about the } \\
\text { characteristics of } \\
\text { cultural and historical } \\
\text { heritage values of } \\
\text { Tekkeköy district }\end{array}$ & $\begin{array}{l}\text { Tekkeköy } \\
\text { District }\end{array}$ & $\begin{array}{l}\text { Trip of Archaeological } \\
\text { Valley, Visiting of Turkey's } \\
\text { First Replica Museum. }\end{array}$ \\
\hline $\begin{array}{l}\text { Natural and } \\
\text { cultural heritage } \\
\text { values of Bafra } \\
\text { district }\end{array}$ & $\begin{array}{l}\text { Workshop about the } \\
\text { characteristics of The } \\
\text { Kizllirmak Delta bird } \\
\text { paradise and cultural } \\
\text { heritage values of } \\
\text { Bafra District }\end{array}$ & $\begin{array}{l}\text { The Kizılırmak } \\
\text { Delta Bird } \\
\text { Paradise and } \\
\text { Bafra District }\end{array}$ & $\begin{array}{l}\text { Trip of The Kizilirmak Delta } \\
\text { Bird Paradise, Birdwatching } \\
\text { and examining the UNESCO } \\
\text { Natural Heritage List process } \\
\text { of the site. İkiztepe Höyüğ̈ü } \\
\text { (Tumulus), Çetinkaya Bridge, } \\
\text { visiting of Bafra Tobacco } \\
\text { Museum, Tasting of Bafra } \\
\text { nokul and pita. }\end{array}$ \\
\hline $\begin{array}{l}\text { Natural and } \\
\text { cultural heritage } \\
\text { values of } \\
\text { Vezirköprü } \\
\text { district }\end{array}$ & $\begin{array}{l}\text { Workshop about the } \\
\text { characteristics of natural } \\
\text { and cultural heritage } \\
\text { values of Vezirköprü } \\
\text { district. }\end{array}$ & $\begin{array}{l}\text { Vezirköprü } \\
\text { District }\end{array}$ & $\begin{array}{l}\text { Boat excursion at Şahinkaya } \\
\text { Canyon, visiting of } \\
\text { Oymaağaç Höyüğ̈̈ } \\
\text { (Tumulus), visiting of } \\
\text { historical streets and city } \\
\text { museum in the district center }\end{array}$ \\
\hline
\end{tabular}




\begin{tabular}{|c|c|c|c|}
\hline $\begin{array}{l}\text { Historical } \\
\text { heritage values of } \\
\text { Havza district }\end{array}$ & $\begin{array}{l}\text { Workshop about the } \\
\text { characteristics of } \\
\text { historical heritage } \\
\text { values of Havza district }\end{array}$ & $\begin{array}{l}\text { Havza } \\
\text { District }\end{array}$ & $\begin{array}{l}\text { Visiting of Havza Atatürk } \\
\text { House and historical sites, } \\
\text { Tasting of Tirit (roasted } \\
\text { goose meat on bulgur pilaf) }\end{array}$ \\
\hline
\end{tabular}

After the implementation. At the end of the project trips that lasted approximately three months, the same study group was asked to write down the names of the places that they know in Samsun, to mark the locations of these places, and to draw them on A4 papers at the center of which a blank map of Samsun without a scale was present. The sampling group was given the same duration as in the pretest, and they were asked to make the drawings collectively in the same environment. In the last section of the study, the urban image elements were indicated in two different maps of Samsun, the data were digitized with the help of the ArcInfo 10 program, and different combined perception maps belonging to different themes were obtained as the first map and the last map.

\section{Data Analysis}

Mind maps drawn by two different groups were examined by researchers and subjected to content analysis. However, during the collection of the data, the drawings of the individuals who did not participate in the first phase of the study and did not participate in the second phase (two people) or the individuals who did not participate in the first phase and drew the map by participating in the second phase (three people) were not analyzed. In all, the mind maps of 15 disabled students were analyzed. In the content analysis process, the drawings, caricatures, pictures, schemes, and writings of the students about Samsun have been taken into consideration. In this way, the data are organized and interpreted so that the readers can understand them easily (Yildirim \& Şimşek, 2008). In the first place, the data have been named and classified, then they have been assigned to categories. Through the analysis of the data, six different themes have been determined, namely living place (natural, social, and cultural values in the living places), natural heritage values, gastronomic culture values, historical and cultural heritage values, districts, famous persons of Samsun, and the others (the values consisting of the elements that represent the personal features of the individual). Then the contents of the pretest and posttest mind maps have been quantified in the forms of frequency (f), percentage (\%), and change rates. The frequencies (f) and percentages (\%) of the contents representing the themes have been examined, and the distribution maps of the pretest and posttests theme contents have been drawn up accordingly. The reports illustrating the research steps have been prepared in detail within the scope of the validity studies, and experts' opinions have been taken in the process. Moreover, two experts taking part in the preparation of mind maps or similar studies and giving courses in the certificate program of pedagogic formation have been asked to create the theme groups regarding the contents in order to ensure reliability. Reliability analyses have been carried out on these themes and contents with the help of the MilesHuberman Model (1994). The agreement among the coders is expected to be $70 \%$ according to the coding check demonstrating the internal consistency (Miles \& Huberman, 1994). The reliability of the content analysis in the present study has been 
calculated as $88 \%$ according to the Miles-Huberman Model. The samples of pretest and posttest mind maps drawn before and after the project are given in Figure 1.

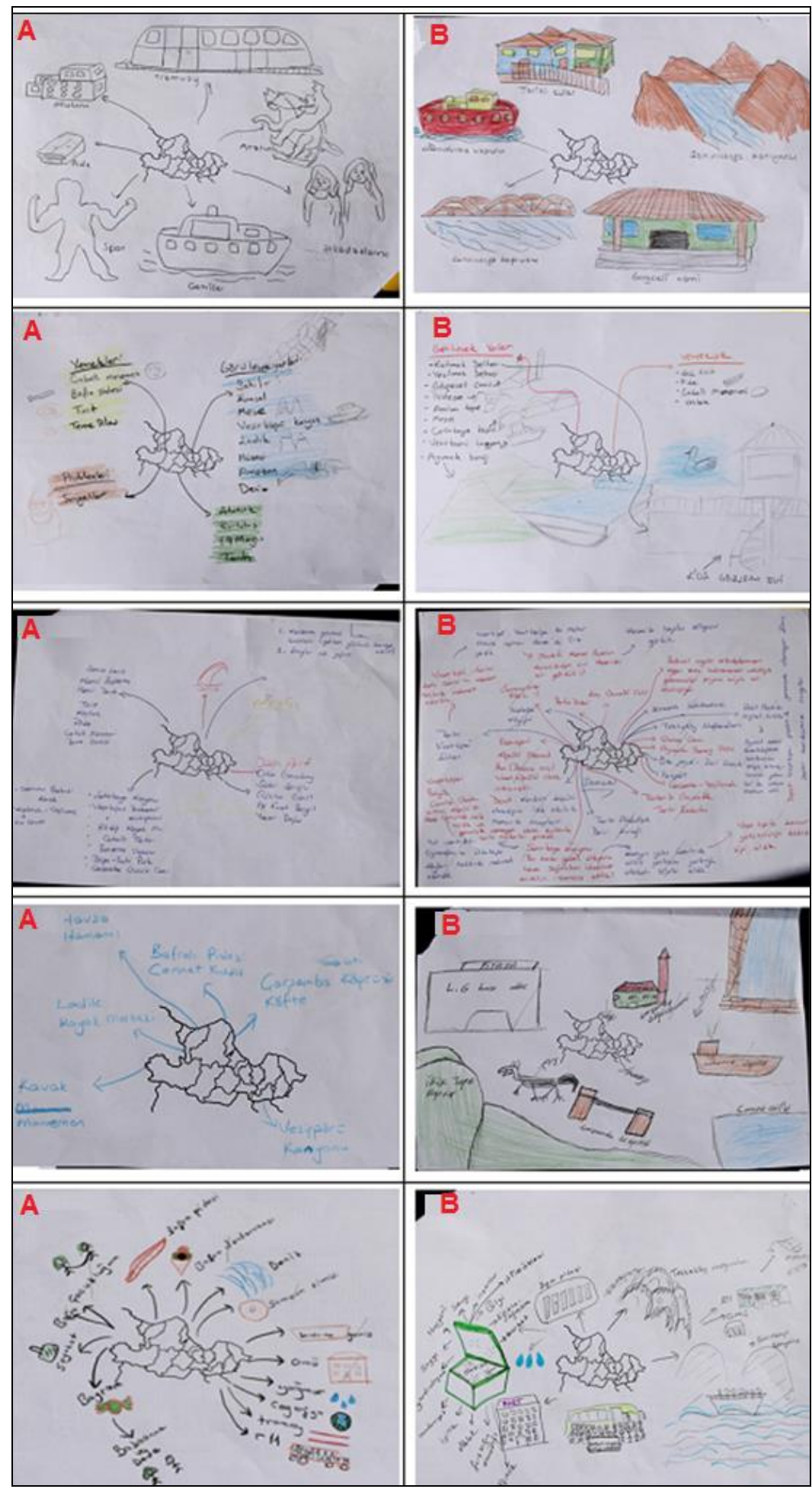

Figure1. Representative examples of student prepared mind maps in pretest (A) and posttest (B). 


\section{Findings}

Table 3 illustrates the development in the knowledge and perception of the disabled students about Samsun through time and experience.

Table 3

The development rate of frequencies which belongs to the theme groups and their contents that include the city-related perceptions towards Samsun and which was obtained as a result of content analyses of pretests and posttests mind maps

\begin{tabular}{lccccc}
\hline & \multicolumn{2}{c}{ Pretest } & \multicolumn{2}{c}{ Posttest } & Development \\
\hline Themes & f & \% & f & \% & \% \\
\hline Living Place & 32 & 25,6 & 39 & 20,42 & 21,88 \\
\hline Natural Heritage & 16 & 12,8 & 55 & 28,8 & 243,75 \\
\hline Cultural and Historical Heritage & 19 & 15,2 & 45 & 23,57 & 136,84 \\
\hline Districts & 8 & 6,4 & 14 & 7,32 & 75 \\
\hline Gastronomic Culture & 26 & 20,8 & 30 & 15,8 & 15,38 \\
\hline Samsun famous persons & 10 & 8,0 & 1 & 0,52 & $-90,0$ \\
\hline Other & 14 & 11,2 & 7 & 3,66 & $-50,0$ \\
\hline Total & $\mathbf{1 2 5}$ & $\mathbf{1 0 0 , 0}$ & $\mathbf{1 9 1}$ & $\mathbf{1 0 0 , 0}$ & $\mathbf{2 3 8 , 7 5}$ \\
\hline
\end{tabular}

According to table 3, when we look at the theme groups and the frequencies and development rates of Samsun city perception obtained from the content analyses of pretest and posttest mind maps, it is seen that the theme content of living area, natural heritage, historical and cultural values districts and gastronomy cult has increased. The greatest increase was in the theme of natural heritage. In contrast, the content of celebrities and other themes representing Samsun has been reduced.

Table 4

The development rate of frequencies which belongs to the living place theme and their contents that include the city-related perceptions towards Samsun and which was obtained as a result of content analyses of pretests and posttests mind maps

\begin{tabular}{llllccc}
\hline \multirow{2}{*}{ Theme } & \multicolumn{1}{c}{$\begin{array}{c}\text { Defined Urban } \\
\text { Perception }\end{array}$} & \multicolumn{2}{c}{ Pretest } & \multicolumn{2}{c}{ Posttest } & Development \\
\cline { 2 - 7 } & B & \% & f & \% & \% \\
\hline & Beach- sea & 12 & 37,49 & 10 & 25,64 & $-16,66$ \\
\cline { 2 - 7 } & University & 4 & 12,50 & 8 & 20,52 & 100 \\
\cline { 2 - 7 } & Shopping mall & 4 & 12,50 & 7 & 17,95 & 75 \\
\cline { 2 - 7 } Living Place tramway-bus & 4 & 12,50 & 7 & 17,95 & 75 \\
\cline { 2 - 7 } & Dormitory & 3 & 9,38 & 2 & 5,12 & $-33,33$ \\
\cline { 2 - 7 } & Sport & 3 & 9,38 & - & - & - \\
\cline { 2 - 7 } & Square & 2 & 6,25 & 2 & 5,12 & 0 \\
\cline { 2 - 7 } & Park & - & - & 3 & 7,70 & - \\
\cline { 2 - 7 } & Total & $\mathbf{3 2}$ & $\mathbf{1 0 0 , 0}$ & $\mathbf{3 9}$ & $\mathbf{1 0 0 , 0}$ & $\mathbf{2 2 , 5 8}$ \\
\hline
\end{tabular}

It is observed that the urban perception content defined by the theme of living place encoded in minds by individuals with disabilities increased before and after the sightseeing studies. According to the preliminary mind maps, the frequencies of university, shopping center, tram-bus content increase, the frequencies of beach-sea and 
dormitory content decrease, and the sports content is not seen at all in the posttest mind maps. A new content was added as "park" on posttest mind maps while the frequency of the challenge content remained the same.

Table 5

The development rate of frequencies which belongs to the natural heritage theme and their contents that include the city-related perceptions towards Samsun and which was obtained as a result of content analyses of pretests and posttests mind maps

\begin{tabular}{|c|c|c|c|c|c|c|}
\hline \multirow{2}{*}{ Theme } & \multirow{2}{*}{$\begin{array}{c}\text { Defined Urban } \\
\text { Perception }\end{array}$} & \multicolumn{2}{|c|}{ Pretest } & \multicolumn{2}{|c|}{ Posttest } & \multirow{2}{*}{$\frac{\text { Development }}{\%}$} \\
\hline & & $\mathbf{f}$ & $\%$ & $\mathbf{f}$ & $\%$ & \\
\hline \multirow{8}{*}{$\begin{array}{l}\text { Natural } \\
\text { Heritage }\end{array}$} & Akdağ Ski Center & 5 & 31,25 & 5 & 9,09 & 0 \\
\hline & Şahinkaya Canyon & 5 & 31,25 & 12 & 21,82 & 140 \\
\hline & $\begin{array}{l}\text { The Kizılırmak } \\
\text { Delta Bird Paradise }\end{array}$ & 4 & 25,0 & 12 & 21,82 & 200 \\
\hline & $\begin{array}{l}\text { Kızilırmak River } \\
\text { Yesilırmak River }\end{array}$ & 2 & 12,50 & 5 & 9,09 & 150 \\
\hline & Yeşilırmak Delta & - & - & 5 & 9,09 & - \\
\hline & $\begin{array}{l}\text { Ayvac1k } \\
\text { Surroundings }\end{array}$ & - & - & 9 & 16,37 & - \\
\hline & Wild Horses-Buffalo & - & - & 7 & 12,72 & - \\
\hline & Total & 16 & 100,0 & 55 & 100,0 & 243,75 \\
\hline
\end{tabular}

When compared to the pretest mind maps, it is observed that there is a great increase in the content of defined urban perception included in the theme of natural heritage in the posttest maps. The frequencies have risen in the contents of Şahinkaya Canyon, Kızılırmak River Basin, and Bird Paradise, Kızılırmak, and Yeşilırmak in the posttest mind maps in comparison with the pretest mind maps while the frequency of Akdağ Ski Resort has not changed in the posttests. In the posttest mind maps, new content has been added as Ayvacık and its surroundings, wild horses-buffalo and Yeşilırmak Delta to the natural heritage areas. What is noteworthy is the increase in the frequency of natural heritage sites where sightseeing and observation works are carried out at different times with the disabled.

The distribution map of the natural heritage areas representing Samsun in the pretest and posttest mind maps of the disabled students has been drawn up at the end of the research through the analyses of these mind maps [Figures 2-3]. It has been found out that there is a significant change in the distribution of the perceptions of the study group regarding the natural heritage values about Samsun in the pretest and posttest mind maps. 


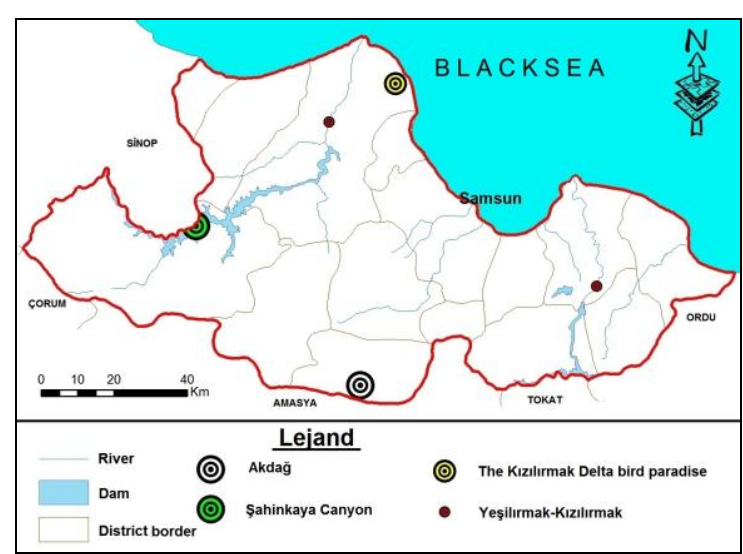

Figure 2. Distribution map of natural heritage in pretest mind maps

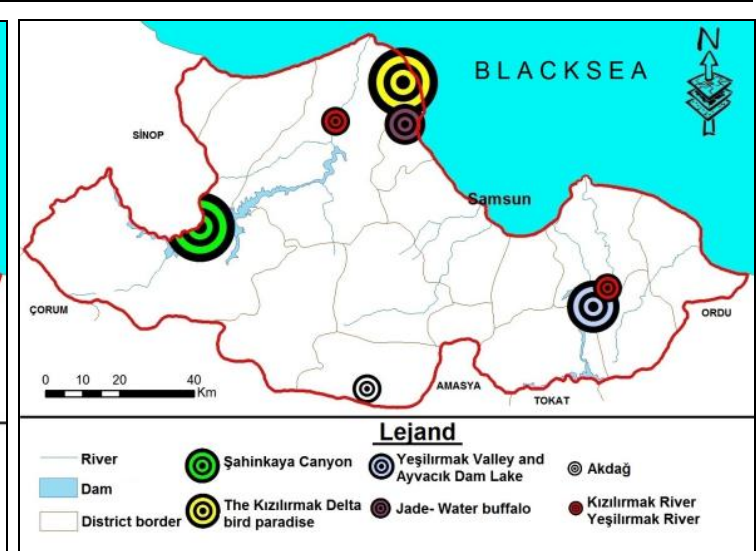

Figure 3. Distribution map of natural heritage in posttest mind maps

Table 6

The development rate of frequencies which belongs to the cultural and historical heritage theme and their contents that include the city-related perceptions towards

Samsun and which was obtained as a result of content analyses of pretests and posttests mind maps

\begin{tabular}{|c|c|c|c|c|c|c|}
\hline \multirow{2}{*}{ Theme } & \multirow{2}{*}{$\begin{array}{l}\text { Defined Urban } \\
\text { Perception }\end{array}$} & \multicolumn{2}{|c|}{ Pretest } & \multicolumn{2}{|c|}{ Posttest } & \multirow{2}{*}{$\begin{array}{c}\begin{array}{c}\text { Developmen } \\
\text { t }\end{array} \\
\%\end{array}$} \\
\hline & & $\mathbf{f}$ & $\%$ & $\mathbf{f}$ & $\%$ & \\
\hline \multirow{13}{*}{$\begin{array}{l}\text { Cultural and } \\
\text { Historical } \\
\text { Heritage }\end{array}$} & Bandırma Steamer & 7 & 36,84 & 6 & 13,34 & $-14,28$ \\
\hline & Atatürk Monument & 3 & 15,79 & - & - & - \\
\hline & $\begin{array}{l}\text { Turkish War of } \\
\text { Independence }\end{array}$ & 3 & 15,79 & - & - & - \\
\hline & İkiztepe Tumulus & 2 & 10,53 & 8 & 17,78 & 300 \\
\hline & Semovar & 2 & 10,53 & 2 & 4,44 & 0 \\
\hline & Amisos Terp & 1 & 5,26 & 3 & 6,66 & 200 \\
\hline & Amazon Woman & 1 & 5,26 & - & - & - \\
\hline & $\begin{array}{l}\text { Havza thermal } \\
\text { spring }\end{array}$ & - & - & 4 & 8,88 & - \\
\hline & $\begin{array}{l}\text { Göğceli Wooden } \\
\text { Mosque }\end{array}$ & - & - & 8 & 17,78 & - \\
\hline & Tekkeköy Caves & - & - & 6 & 13,34 & - \\
\hline & $\begin{array}{l}\text { Bedesten and } \\
\text { Library }\end{array}$ & - & - & 6 & 13,34 & - \\
\hline & Atatürk's House & - & - & 2 & 4,44 & - \\
\hline & Total & 19 & 100,0 & 45 & 100,0 & 136,84 \\
\hline
\end{tabular}

It is seen that there is a remarkable increase in the content of the defined urban perception included in the historical and cultural heritage themes in the posttest maps in comparison with the pretest mind maps. The frequencies of the contents of İkiztepe and Amisos Hills have risen in the posttest mind maps whereas a decrease has been observed in the frequency of Bandirma Steamboat. The frequency of samovar content 
has not changed in both mind maps. The contents such as Atatürk Statue, liberation road and Amazon Woman have not been included in the posttest mind maps whereas new contents such as Havza Thermal Spring, Nailless Mosque, Tekkeköy Caves, Atatürk's House, Bazaar, and Library have been added to the posttest mind maps.

When the pretest and posttest mind maps of the disabled students are compared, it is seen that there is a significant change in the distribution of the perceptions regarding the historical and cultural heritage values in Samsun [Figures 4-5]. The values that are located mainly in the city center and which are easily accessible by the disabled (such as Bandirma Steamboat, Atatürk Statue, Liberation Road, Amisos Hill, and Amazon Woman) are more prominent in the pretest mind maps while İkiztepe, Nailless Mosque (Göğceli), Tekkeköy Caves, Vezirköprü Bazaar are included in the posttest mind maps of the students.

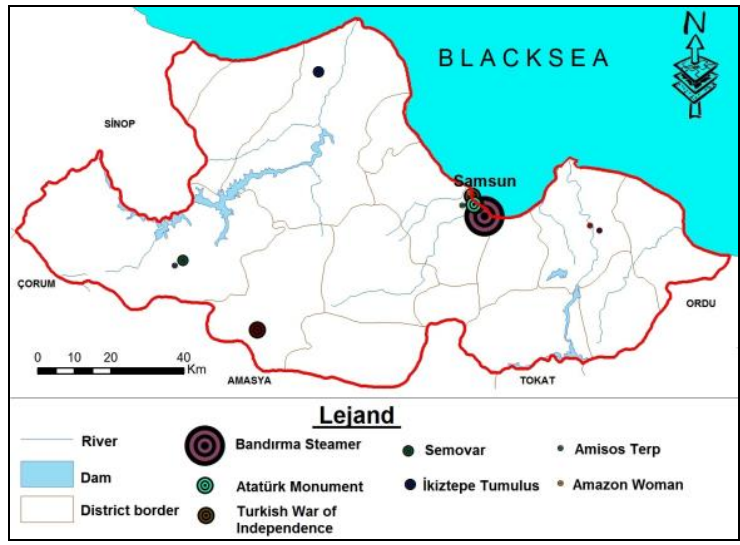

Figure 4. Figure 4. Distribution map of Cultural and Historical Heritage in pretest mind maps

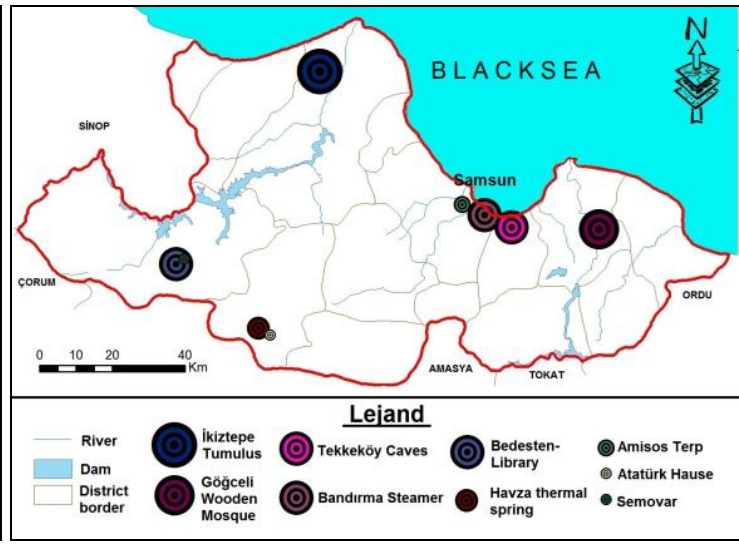

Figure 5. Distribution map of Cultural and Historical Heritage in posttest mind maps

Table7

The development rate of frequencies which belongs to the districts theme and their contents that include the city-related perceptions towards Samsun and which was obtained as a result of content analyses of pretests and posttests mind maps

\begin{tabular}{|c|c|c|c|c|c|c|}
\hline \multirow{2}{*}{ Theme } & \multirow{2}{*}{$\begin{array}{l}\text { Defined Urban } \\
\text { Perception }\end{array}$} & \multicolumn{2}{|c|}{ Pretest } & \multicolumn{2}{|c|}{ Posttest } & \multirow{2}{*}{$\begin{array}{c}\begin{array}{c}\text { Developmen } \\
\text { t }\end{array} \\
\%\end{array}$} \\
\hline & & $\mathbf{f}$ & $\%$ & $\bar{f}$ & $\%$ & \\
\hline \multirow{9}{*}{ Districts } & Kavak & 3 & 37,50 & - & - & - \\
\hline & Bafra & 2 & 25,0 & - & - & - \\
\hline & Ladik & 1 & 12,50 & - & - & - \\
\hline & Havza & 1 & 12,50 & - & - & - \\
\hline & Vezirköprü & 1 & 12,50 & 3 & 21,42 & 200 \\
\hline & Çarşamba & - & - & 4 & 28,58 & - \\
\hline & Atakum & - & - & 4 & 28,58 & - \\
\hline & İlkadım & - & - & 3 & 21,42 & - \\
\hline & Total & 8 & 100,0 & 14 & 100,0 & 75 \\
\hline
\end{tabular}


There is a significant change in the content of defined urban perception in the theme of districts in the posttest mind maps in comparison with the pretest mind maps. The districts of Kavak, Bafra, Ladik, and Havza that have been specified in the pretest mind maps are not included in the posttest mind maps. Instead of these districts, Çarşamba, Atakum, and İlkadım districts are listed in the posttest mind maps. Vezirköprü district is indicated both in the pretest and posttest mind maps, and the frequency of the district has been seen to increase in the posttest maps. When the distribution maps illustrating the difference between the pretest mind maps and posttest mind maps are examined in the content of the relevant theme, it is seen that the districts included in the contents of the mind maps have changed [Figures 6-7].

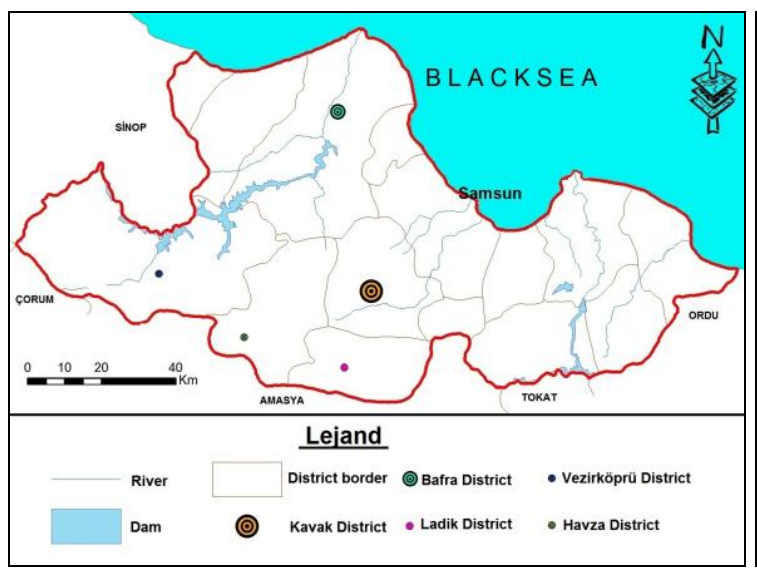

Figure 6. Distribution map of districts in pretest mind maps

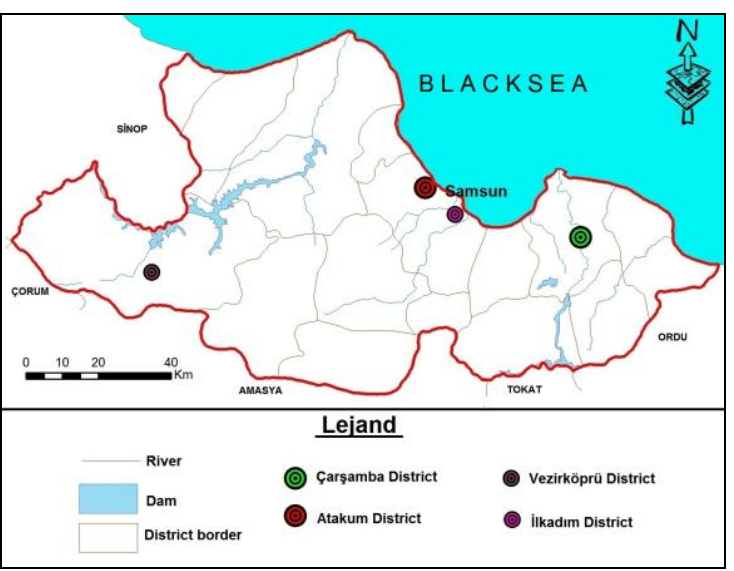

Figure 7. Distribution map of districts in posttest mind maps

Table 8

The development rate of frequencies which belongs to the gastronomic culture theme and their contents that include the city-related perceptions towards Samsun and which was obtained as a result of content analyses of pretests and posttests mind maps

\begin{tabular}{|c|c|c|c|c|c|c|}
\hline \multirow{2}{*}{ Theme } & \multirow{2}{*}{$\begin{array}{l}\text { Defined Urban } \\
\text { Perception }\end{array}$} & \multicolumn{2}{|c|}{ Pretest } & \multicolumn{2}{|c|}{ Posttest } & \multirow{2}{*}{$\begin{array}{c}\begin{array}{c}\text { Developmen } \\
\text { t }\end{array} \\
\%\end{array}$} \\
\hline & & $\mathbf{f}$ & $\%$ & $\mathbf{f}$ & $\%$ & \\
\hline \multirow{12}{*}{$\begin{array}{l}\text { Gastronomic } \\
\text { Culture }\end{array}$} & Pita & 12 & 46,16 & 12 & 40,1 & 0 \\
\hline & Menemen & 4 & 15,39 & 1 & 3,33 & -75 \\
\hline & Tirit & 3 & 11,54 & 9 & 30,0 & 200 \\
\hline & Terme pilaf & 2 & 7,69 & - & - & - \\
\hline & Çarşamba meatball & 2 & 7,69 & 1 & 3,33 & 50 \\
\hline & Simit (Turkish bagels) & 2 & 7,69 & - & - & - \\
\hline & Tea & 1 & 3,84 & - & - & - \\
\hline & Bafra ice-cream & - & - & 3 & 10,0 & - \\
\hline & Stuffed mussels & - & - & 2 & 6,67 & - \\
\hline & Keşkek & - & - & 1 & 3,33 & - \\
\hline & Oymaağaç kebab & - & - & 1 & 3,33 & - \\
\hline & Total & 26 & 100,0 & 30 & 100,0 & 15,38 \\
\hline
\end{tabular}


When the pretest mind maps are compared with the posttest mind maps, it is understood that Bafra Pita is accepted as the most important element of Samsun's gastronomic culture in the perceptions of the disabled students. However, it should not be disregarded that the numbers and frequencies of the other values in Samsun's gastronomic culture have increased in the posttest mind maps when compared to the pretest mind maps.

Table 9

The development rate of frequencies which belongs to the Samsun celebrities theme and their contents that include the city-related perceptions towards Samsun and which was obtained as a result of content analyses of pretests and posttests mind maps

\begin{tabular}{|c|c|c|c|c|c|c|}
\hline \multirow{2}{*}{ Theme } & \multirow{2}{*}{$\begin{array}{l}\text { Defined Urban } \\
\text { Perception }\end{array}$} & \multicolumn{2}{|c|}{ Pretest } & \multicolumn{2}{|c|}{ Posttest } & \multirow{2}{*}{$\frac{\text { Development }}{\%}$} \\
\hline & & f & $\%$ & $\mathbf{f}$ & $\%$ & \\
\hline \multirow{9}{*}{$\begin{array}{l}\text { Famous People } \\
\text { of Samsun }\end{array}$} & Orhan Gencebay & 3 & 30,0 & - & - & - \\
\hline & Ozan Arif & 2 & 20,0 & - & - & - \\
\hline & Yaşar Doğu & 1 & 10,0 & - & - & - \\
\hline & Ufuk Özkan & 1 & 10,0 & - & - & - \\
\hline & Levent Kirca & 1 & 10,0 & - & - & - \\
\hline & Ali Fuat Başgil & 1 & 10,0 & - & - & - \\
\hline & Sabri Sarığlu & 1 & 10,0 & - & - & - \\
\hline & $\begin{array}{l}\text { Köprülü Mehmet } \\
\text { Pasha }\end{array}$ & - & - & 1 & 100,0 & - \\
\hline & Total & 10 & 100,0 & 1 & 100,0 & -90 \\
\hline
\end{tabular}

The reduction in the content of vowels identified with Samsun in the posttest mind maps is remarkable. While the first mind maps featured popular artists and footballers of today, the last mind maps contained none of them but Köprülü Mehmet Pasha, who identified only with Vezirköprü.

Table 10

The development rate of frequencies which belongs to the other theme and their contents that include the city-related perceptions towards Samsun and which was obtained as a result of content analyses of pretests and posttests mind maps

\begin{tabular}{rlllllc}
\hline \multirow{2}{*}{ Theme } & $\begin{array}{l}\text { Defined Urban } \\
\text { Perception }\end{array}$ & \multicolumn{2}{c}{ Pretest } & \multicolumn{2}{c}{ Posttest } & $\begin{array}{c}\text { Improvemen } \\
\text { t }\end{array}$ \\
\cline { 2 - 7 } & F & $\mathbf{\%}$ & $\mathbf{f}$ & $\mathbf{\%}$ & $\mathbf{\%}$ \\
\hline \multirow{5}{*}{ Other } & $\begin{array}{l}\text { Medikal doctor- } \\
\text { inject- medications }\end{array}$ & 4 & 28,58 & - & - & - \\
\cline { 2 - 7 } & Weapon-bullet & 3 & 21,43 & 2 & 28,57 & $-33,33$ \\
\cline { 2 - 7 } & Damp-rain & 3 & 21,43 & 4 & 57,15 & 33,33 \\
\cline { 2 - 7 } & Exam ination & 2 & 14,28 & - & & - \\
\cline { 2 - 7 } & Green & 1 & 7,14 & 1 & 14,28 & 0 \\
\cline { 2 - 7 } & Syrians & 1 & 7,14 & - & & - \\
\cline { 2 - 7 } & \multicolumn{1}{c}{ Total } & $\mathbf{1 4}$ & $\mathbf{1 0 0 , 0}$ & $\mathbf{7}$ & $\mathbf{1 0 0 , 0}$ & $\mathbf{- 5 0}$ \\
\hline
\end{tabular}

The content of the other themes has significantly decreased in the posttest maps when compared to the pretest mind maps. The specific notions such as examination, 
Syrians, medical doctors, medications, and injections have been frequently repeated in the pretest mind maps, such issues are not specified in the posttest mind maps.

\section{Result and Discussion}

In this research, the nature of changes in the knowledge and perceptions of disabled persons regarding the places where they live has been discussed by focusing on sightseeing studies. The research has been carried out with an experimental method. The first step of the present study has analyzed the themes that have been determined for the representation of Samsun city in the minds of the disabled students by elaborating on their mind maps. The perceptions about Samsun have been categorized into six themes in the mind maps of the disabled students before and after the trips. These themes are the living places, historical and cultural heritage, natural heritage, districts, famous people in Samsun, and gastronomic culture. Apart from these, there are also a number of individualized elements (other) in the minds of disabled people that do not contain any themes. The main themes in the pretest and posttest mind maps have a very high similarity rate. In contrast, the presence of statistical changes in theme content and frequencies of content is remarkable. Although content change is seen in all themes, Samsun celebrities draw attention as a theme in which the entire content changes. The reason for the change of this theme is that Samsun celebrities are not included in the contents of the activities given before the research. In other words, the celebrities of Samsun in the preest mind maps of individuals are celebrities who are frequently on the agenda in social media and in the visual-print media. Besides, the visit to Anitpark in Vezirköprü district during the sightseeing activities has enabled the inclusion of Köprülü Mehmet Paşa in the posttest theme content. The changes in theme contents have continued with the other themes (4), gastronomic culture (3), districts (3), historical and cultural heritage (3), and living places (1). Apart from these, all of the contents given in the theme of natural heritage in the pretest mind maps are also included in the posttest mind maps, and the content of this theme has changed in the posttest. In other words, it can be asserted that the promotion-oriented and educationbased trips designed for disabled people have developed the content of their perceptions about Samsun city. The studies supporting this outcome have revealed that the disability condition, time, experience, and interest allocated to a specific location cause significant changes in the perception styles of people about that location and that this change is reflected in the mind maps of the individuals (Üçışık Erbilen, 2012, p. 157; Aliağaoğlu \& Uğur, 2010, p. 202). Similarly, Temurçin \& Keçeli (2015, p. 132) point out that the mind maps of individuals change at lower or higher degrees according to the time, living style and experience. In light of these remarks, it can be stated that the sightseeing method becomes a supplementary tool for reducing the concerns of disabled persons about their disabilities and enabling them to know the places they live in and to interact with other people by enlarging their active environment. Therefore, Genç \& Çat (2013, p.363) draws attention to the fact that expanding the field of social activity such as participation in the work force in disabled individuals contributes to the solution of many problems of disabled individuals and their socialization. In addition, Başkonak (2019, P.88. ) studying the lessons with techniques such as observation trip increases the interest of the hearing impaired, especially abstract concepts are helped to include. 
When the contents included in the other theme are analyzed within the scope of this study, it is seen that the medical contents such as medical doctors, medications, and injections have been specified in the pretest mind maps of the disabled as a result of their current conditions. However, the contents of medical doctors, medications, and injections are not included in the posttest mind maps of the participants. The lack of these negative items in the posttest mind maps of the disabled can be considered as the elimination of the negative thoughts on their physical disabilities with the help of the project. In the study carried out by Südaş \& Öz $(2018$, p. 90), it has been reported that the places where the students frequently spend their time such as the universities and dormitories are more easily perceived and represented in the cognitive maps of students. Similarly, different studies underline the positive physical and psychological impacts of sightseeing activities in natural environments on disabled people (Corazon, Stigsdotter, Moeller \& Rasmussen, 2012; Hartig, Mitchell, De Vries \& Frumkin, 2014; Pouya, Bayramoğlu \& Demirel, 2015). Moreover, Pouya \& Demirel (2018, p. 786) have pointed out that sightseeing studies have created positive impacts on the children suffering from cerebral palsy, and that such activities make great contributions to the development of motor activities, language, social and emotional attitudes, and self-care.

In addition to the location factor, the frequent, rare, or non-use of a specific place directly influences the representation of the place in the mind maps (Südaş \& Öz, 2018, p. 90). In other words, the use of urban areas and the needs for these places are considered to be among the most significant factors influencing the perception of those areas (Göregenli, 2015). When the pretest and posttest mind maps of the study group are analyzed, it is observed that the living places of the disabled and their milieus are at the center in the first mind maps whereas the perceived locations and their contents have significantly expanded in the last mind maps. On the other hand, the sea and beach play an important role in the living places of disabled persons in Samsun. In other words, the living places of the disabled have squeezed in the triangle of the beach-dormitoryshopping mall and the transportation systems (tramway and shuttle bus) in Samsun. Tümertekin \& Özgüç (2009, p. 53) state that the places where the individuals spend most of their time will be easily remembered, and that this recollection will reflect into the mind maps of those individuals. In other words, apart from the locations introduced with the sightseeing activities, the places where the disabled frequently and actively go around have played a significant role in the formation of their locational perception. In furtherance of this inference, it has been detected that among two Turkish workers living in Cologne, the mind map of the worker who are well-educated and who went to the city before the other worker was more detailed than the map of the other worker going to the city later and being less-educated (Clark, 1977, cited in Tümertekin \& Özgüç, 2009, p.54).

It is seen that the defined urban perception regarding the history of the city and cultural heritage sites includes the easily-accessible places (such as Bandirma Steamboat and Atatürk Statue) at the city center which are near to the living places of the disabled in the pretest mind maps. However, in the posttest mind maps drawn after the sightseeing activities, it has been observed that the visited places have positively changed the contents regarding Samsun's history and cultural heritage, and that the 
contents have included the heritage sites far from the living places of the disabled (such as Havza Thermal Spring, Atatürk's House, Göğceli Mosque, etc.) in the posttest mind maps of the students. Environmental perception can change according to personal characteristics of the individuals; on the other hand, these changes can mostly derive from the previous experiences of the persons as well as the use of natural, historical, and cultural areas (Lynch, 1960). Similarly, in this study, the visit to different historical and cultural values symbolizing Samsun city and students' experiences in these areas have played a significant role in the alterations recorded in the posttest mind maps of the participants.

No development has been observed in the content of district theme in contrast to the development in the distribution of the theme contents regarding the natural heritage areas, historical and cultural heritage values and gastronomic culture in favor of the places visited within the scope of sightseeing activities. Whereas more districts have been specified in the pretest mind maps, the number of the districts has decreased in the posttest mind maps and the districts that are not included in the study have been added to the mind maps. The place that an individual lives in influences his/her locational perception (Tümertekin \& Özgüç, 2009, p. 52). Moreover, the period in which the individuals live is an important factor affecting the perceived location and the perception about that area (Göregenli \& Melek, 2015, p. 197). For this reason, the inclusion of Atakum and İlkadım districts -where the participants live- in the mind maps of disabled students explains the oppositeness in the district variable in comparison with other values.

Mind maps are a dynamic phenomenon shaped by one's experiences or knowledge acquired. Therefore, it differs more or less from individual to individual, time, frequency and shape of the activity. The handicapped individuals in the study group, which is the point of all this Samsun natural, historical and cultural values in perceptions on the sightseeing method is applied at the end of the project a notable increase in the positive direction, Samsun has experienced great growth and change in mind-maps. In other words, the knowledge of the students on the natural, historical, and cultural values of Samsun has greatly developed after the sightseeing activities whereas the first knowledge and perceptions of these students generally focused on the physical and social environment around them and the dormitory and university campus. This study has developed the process of scientific awareness on the positive changes in locational perception of disabled persons with the help of an increase in the sightseeing activities, the elimination of obstacles limiting the access of the disabled to different values in the places where they live, and the implementation of various projects enabling these people to have access to different locations. In the future, more importance should be attached to all different contexts with which the disabled wish to have interaction both physically and technically. Similarly in Genç $(2015$, p.65) states that economic assistance to disabled individuals and their families is not sufficient for them to live a healthy life and be happy, and that they want to participate in social life. In order to overcome this, however, there is a need for politicians, social theorists or geographers besides socio-cultural studies, geographic studies for disabled people. 


\section{Acknowledgement}

The data used in this study have been collected from Barrier-free Evliya Çelebis Project of OMU supported by the Ministry of Youth and Sports.

\section{References}

Açar, S. (2010). The effects of expedition in social studies lesson in primary school on the field of trip students? Critical thinking skill and environmental sensitivity (Master dissertation). Onsekiz Mart University, Çanakkale. Retrieved from https://tez.yok.gov.tr/UlusalTezMerkezi/tezSorguSonucYeni.jsp

Akbaş, Y., \& Toros, S. (2016). Pre-service elementary teachers' geographic information sources and world images in their mind maps. Eastern Geographical Review, 21(36), 201-224.

Akgün, A., Duruk, Ü, \& Tokur, F. (2017). Investigation of the field trip methods' effectiveness: As a way of improving preservice teachers' views on environmental education. Route Educational and Social Science Journal, 4(2), 65-82.

Aliağaoğlu, A. (2007). An example to behavioral geography: Student centered Balıkesir city image. Firat University Journal of Social Science, 17, 17-44.

Aliağaoğlu, A., \& Uğur, A. (2010). Şehir coğrafyası. Ankara: Nobel Yayın Dağıtım.

Arı, Y. (2017). From environmental determinizm to political ecology: Approaches in humanenvironment geography in the world and in Turkey during the last 100 years. Eastern Geographical Review, 22(37), 1-34.

Aytaç, A. (2014). The place and importance of the field trip method for the social science teacher candidates' education. HAYEF: Journal of Education, 11(1), 55-69.

Balım, A. G., Aydın, G., \& Evrekli, E. (2006 Nisan). The importance of using mind maps and concept maps in science and technologyteaching. In H. Yaratan, (Eds.), VI. International Educational Technologies Conference (213-224). Turkish Republic of Northern Cyprus (TRNC): Eastern Mediterranean University in Gazimagusa.

Başkonak, M. (2019). Türkiye'de işitme engellilerin din eğitimi. Konya: Eğitim Yayınevi.

Baştürk, R (2009). Deneme modelleri. In A. Tanrı̈ğğn (Eds.). Bilimsel Araşırma Yöntemleri. Ankara: Anı Yayıncılık.

Blades, M. (1990). The reliability of data collected from sketch maps. Journal of Environmental Psychology, 10(4), 327-339.

Brennan-Horley C. (2010). Mind mapping the "creative city". Journal of Maps, 6(1), 250-259. DOI: $10.4113 /$ jom.2010.1082

Canbazoğlu Bilici, S. (2019). Örnekleme yöntemleri. In H. Özmen \& O. Karamustafaoğlu (Eds.). Ĕ̈itimde araştırma yöntemleri (55-80). Ankara: Pegem Akademi.

Cengiz Gökçe, G., \&, Açıksöz, S. (2017). The evaluation of the rural landscape identity by mind mapping method: The case of Nallihan Beydili. International Refereed Journal of Design and Architecture, 10, 37-55.

Chouinard, V. (2001). Disability, Geography of. In J. Neil Smelser and P. B. Baltes (Eds.), International Encyclopedia of the Social \& Behavioral Sciences (pp. 3701-3704). Amsterdam: Elsevier.

Clark, J. R. (1977). Turkish Cologne: the mind maps of migrant workers in a German city (No. 19). Dept. of Geography, University of Michigan, Ann Arbor. 
Council of Higher Education (2020). Disabled student statistics of Turkey. Retrieved from https://istatistik.yok.gov.tr/

Corazon, S. S., Stigsdotter, U. K., Moeller, M. S., \& Rasmussen, S. M. (2012). Nature as therapist: Integrating permaculture with mindfulness-and acceptance-based therapy in the Danish Healing Forest Garden Nacadia. European Journal of Psychotherapy \& Counselling, 14(4), 335-347.

Da Vinha, L. (2012). Charting geographic mind maps in foreign policy analysis: A literature review. Human Geographies-Journal of Studies \& Research in Human Geography, 6(1), 6-17. DOI: $10.5719 /$ hgeo.2012.61.5

Dernat, S., Johany, F., \& Lardon, S. (2016). Identifying choremes in mind maps to better understand socio-spatial representations. Cybergeo: European Journal of Geography, 800, 1-25. DOI: $10.4000 /$ cybergeo. 27867

Downs, R. M., \& Stea, D. (1973). Cognitive maps and spatial behavior: Process and products. In R. M. Downs, \& D. Stea (Eds.), Image and environment (pp. 8-26). Chicago: Aldine.

Downs, R. M., \& Stea, D. (1977). Maps in minds: Reflections on cognitive mapping. Newyork: HarperCollins Publishers.

Genç, Y. \&, Çat, G. (2013). Employment of disabled people and social inclusion relationship. Journal of Academic Inquiries, 8(1), 363-393.

Genç, Y. (2015). Social problems and expectations of disabled people. Journal of Social Policy Studies, 35(2), 65-92.

Gieseking, J. J. (2013). Where we go from here: The mental sketch mapping method and its analytic components. Qualitative Inquiry, 19(9), 712-724.

Gleeson, B.J. (1996). A geography for disabled people? Transactions of the Institute of British Geographers, 21(2), 387-396.

Gleeson, B.J. (1999). Geographies of disability. New York and London: Routledge,

Golledge, R. G. (1993). Geography and the disabled: a survey with special reference to vision impaired and blind populations. Transactions of the Institute of British Geographers, 18, (1), 63-85.

Goodier C.I., \& Soetanto R. (2013). Building future scenarios using cognitive mapping. Journal of Maps, 9(2), 203-217. DOI:10.1080/17445647.2013.770997

Göregenli, M. (2015). Çevre psikolojisi: insan mekan ilişkileri. İstanbul Bilgi Üniversitesi Yayınlar1, İstanbul: Matris Matbaa.

Gueben-Venière S. (2011). How can mind maps, applied to the coast environment, help in collecting and analyzing spatial representations? EchoGéo, 17, 1-11. DOI: 10.4000/echogeo. 12625

Gürbüz, S., \& Şahin, F. (2014). Sosyal bilimlerde araştırma yöntemleri. Ankara: Seçkin Yayınc1lik.

Haas V., Levasseur E., Béal A., Charrier L., Demoures A., Kalampalikis N., ... \& Rampon J.M. (2011). Villeurbanne, à la croisée des mémoires (Research report), Université Lumière de, Lyon.

Hartig, T., Mitchell, R., De Vries, S., \& Frumkin, H. (2014). Nature and health. Annual Review of Public Health, 35, 207-228. 
Jacobson, D. (2016). Geography of disability. In Oxford Bibliographies. Retrieved from https://www.oxfordbibliographies.com/view/document/obo-9780199874002/obo9780199874002-0064.xml

Karadeniz, O., Tangülü, Z., \& Melike, F. (2013). The effects of using mind mapping technique in secondary 6.th grade social studies lesson to the students' academic achievements. The Black Sea Journal of Social Sciences, 5(8), 131-142.

Karataş, S. (2010). The analysis of computer education and instructional technologies prospective teachers' mind maps relating to their profession (The case of Gazi University). KEFAD, 11(1), 159-173

Lynch, K. (1960). The imaj of city. MIT Press Cambridge, MASS.

Marvin Levine, E. (1980). Cognitive maps, 1magery and memory for street directions, (Doctoral dissertation), Microfilms International University, England.

Miles, M, B., \& Huberman, A. M. (1994). Qualitative data analysis: An expanded Sourcebook. (2nd ed.). Thousand Oaks, CA: Sage.

Özmen, H. (2019). Deneysel araştırma yöntemi. In H. Özmen \& O. Karamustafaoğlu (Eds.). Eğitimde araştırma yöntemleri (pp. 197-227). Ankara: Pegem Akademi.

Park, D. C., Radford, J. P., \& Vickers, M. H. (1998). Disability studies in human geography. Progress in human geography, 22(2), 208-233.

Pouya, S.; Demirel, Ö. (2018). Positive health effects of the natural environment on children with disability. Journal of Agriculture and Nature, 21(5), 786-799.

Pouya, S., Bayramoğlu, E., \&Demirel, Ö. (2015). Investigation of Healing Garden Design Methods. Kastamonu University Journal of Forestry Faculty, 15(1): 15-25.

Rediscovering Geography Committee (1997). Rediscovering geography: New relevance for science and society. Washington, D.C.: National Academies Press.

Reuchamps M., Kavadias D., \& Deschouwer, K. (2014). Drawing Belgium: using mind maps to measure territorial conflict. Territory, Politics, Governance. 2(1), 30-51. DOI: $10.1080 / 21622671.2013 .814549$

Siochos, V., \& Papatheodorou, C. (2011). Developing a formal model for mind maps. First Workshop on Digital Information Management, 39-44. Retrieved from http://eprints.rclis.org/15842/1/04.Sioc hos.pdf

Sözbilir, M. (2012). Experimental research patterns. Retrieved from https://fenicay.files.wordpress.com/2009/03/hafta-4-deneysel-arac59ftc4b1rmadesenleri.pdf

Südaş, İ., \& Öz, İ. (2018). Cognitive maps in behavioural geography: The case of Ege University Campus. Turkish Geographical Review, 71, 81-92.

Şeyihoğlu, A., Akbaş, Y., \& Kartal, A. (2012). Uygulama örnekleri ile coğrafya eğitiminde kavram ve zihin haritaları. Ankara: Pegem Akademi.

Temurçin K., \& Keçeli, K. (2015) A study of behavioral geography: A case study on the spatial perception of the international students in Isparta. SDU Faculty of Arts and Sciences Journal of Social Sciences, 36, 117-138.

Tümertekin, E., \& Özgüç. N. (2009). Beşeri coğrafya insan-kültür-mekân. İstanbul: Çantay Kitabevi. 
Tunçel, H. (2002). Islamic countries images of Turkish geography students. Firat University Journal of Social Science, 12(2), 83-103.

Türkyılmaz, H. (2017). Mind mapping as an innovative teaching method and its usage in religious education. International Journal of Education Technology and Scientific Researches, 2(3), 148-161.

Üçış1k Erbilen, S. (2012). An example for urban place perception: Famagusta (Ismet Inonu Boulevard). H. U. Journal of Education, Special Issue, 1, 157-166.

Varnacı Uzun, F., \& Altaş A. (2018). Perceptions of Aksaray University students about foodbeverage places in the city center of Aksaray. Journal of Geographical Sciences, 16 (1), $121-134$.

Wartmann, F., \& Purves, R. (2017). What's (not) on the map: landscape features from participatory sketch mapping differ from local categories used in Language. Land, 6 (4), 1-16. DOI: 10.3390/land6040079.

Wise, N., \& Heckley-Kon, J. (1990) Assessing geographic knowledge with sketch maps. Journal of Geography. 89(3), 123-129.

Yıldırım, A. \& Şimşek, H. (2008). Sosyal bilimlerde nitel araştırma yöntemleri (6. Baskı). Ankara: Seçkin Yayıncılık.

Y1lmaz, C., \& Bilgi, G. M. (2011). Geography teacher candidates' overview of the field work. Journal of Educational Sciences: Theory \& Practice, 11(2), 961-983.

Zajadacz, A. (2015). The contribution of the geography of disability to the development of 'accessible tourism'. Turyzm, 25(1), 19-27.

\section{Biographical Statement}

Seyfullah GÜL is an assistant professor at Ondokuz Mayıs University, Faculty of Tourism, and Department of Tourism Guidance. He gives lectures on culture, natural and cultural heritage, tourism and ecology. 